\title{
The Discourses of the Sinking Villages in Demak: The Social Relation between Humans and Nature
}

\author{
Suwarno Peter $^{1}$, Nurhayati Nurhayati ${ }^{2 *}$ \\ ${ }^{1}$ School of International Letters and Cultures, Arizona State University, Tempe - Arizona \\ ${ }^{2}$ Master Program of Linguistics, Faculty of Humanities, Diponegoro University, Semarang - \\ Indonesia
}

\begin{abstract}
Stories of climate change and its impacts on human life that have been reported in various media supports arguments that it is largely manmade. In many Indonesian communities, however, this disaster that alters cultural, social, and economic environment is often viewed as a natural phenomenon. This paper analyzes expressions of the experiences of local Indonesian inhabitants and media reporters using discourse analysis. The selected texts in the reports mostly focus on expressions concerning how the inhabitants dealt with the ever-increasing tidal flood that engulfed their dwellings and communities. The analysis reveal that stories on their experiences contain words and themes representing their views of natural phenomenon that created memories of the past and uncertain plans for the futures. Different types and class of words they express not only represent grieving for loss of livelihood, but also, more importantly, embody efforts to make the best of what is left, including changing the inundated district into a tourism site.
\end{abstract}

Keywords: narrative discourse; tidal flood, social relation; appraisal system

\section{Introduction}

One of the most important international stories in recent decades is climate change and its impacts on human life that has been productively narrated in various media. Most experts attributed this drastic environmental transformation to man-made global warming, creating images that shape cultural, social, and political and economic discourses [1].

The local communities, however, are not necessarily concerned nor aware of such agreements and efforts. They are focused on their local daily survival facing the unstoppable calamity, because they do not see any direct impact of international cooperation on their lives, due to the gap between narrative of the policies with various efforts and the ongoing disaster affecting their lives and livelihood [2].

Indonesia is one of the countries hit the hardest by climate change, producing discourses of regularly occurring disasters. However, for the severely affected local Indonesian

\footnotetext{
* Corresponding author : nurhayati@live.undip.ac.id
} 
inhabitants, the stories reported in the media mostly focus on the relationship between the victims and the disasters that changes their lives and livelihood.

This paper attempts to present expressions, including terms, themes, and images in the reported narratives of the inhabitants in the district of Demak who are losing their dwellings and communities due to sea level rising called "banjir rob" (tidal flood). In this district, some villages have vanished and a large number of displaced inhabitants had to move further inland. Stories on their views and experiences reported in various media containing words and themes representing their views, attitudes, common memories, uncertainties, and survivals.

\section{Research Methods}

Using discourse analysis, especially critical discourse analysis [3, 4] and appraisal system [5], this study examines the conversations of the community members affected by the tidal flood in the district of Demak, reproduced by reporters through news media. The data were gathered from four sources. First is the report series about the Indonesian coastline threatened to sink on the BBC News Indonesia website, downloaded from https://regional.kompas.com/read/2020/03/27/10200071/kisah-satu-keluarga-di-demakbertahan-di-tengah-desa-yang-tenggelam-gunakan?page =all. That is a narrative text about a family that keep staying in the sinking district. Second is the same story, but in the form of video downloaded from https://www.youtube.com/watch? $v=Q Z L Z q G F V-n c$. Third is tourism advertorial text about the sinking district downloaded from https://www.youtube.com/watch? $v=Q Z L Z q G F V-n c$. Fourth is the hard-news texts downloaded from https://jateng.tribunnews.com/2015/09/18/desa-unik-setiap-hari-adawarga-pamit-pindah. This study utilized a common approach used for analyzing discourse that explores how people use language to achieve certain goals in different contexts $[4,6]$. Following Halliday's suggestions [7], this study will look at the way language is portraying the topic or action, involving processes, participants, and circumstances, participants' statuses, roles, and relationships, as well as the channel through which the text is depicted. This study collected and selected the texts based on representativeness and frequency, hopefully generating expressions that reveal their meaning and intent related live changes they have to make.

\section{The Narrative of The Pasijah's Life}

An intriguing documentary report from $\mathrm{BBC}$ news narrated the life of Pasijah (also known as Mak Ijah), a mother of four who recounted drastic changes in her family's life as the sea water eroded her village. As shown in the examples below, these changes filled with past memories of growing rice and corn, until ever-increasing intrusion of sea water forced her and other villagers to farm fish and become fishermen (ex. 1). Unlike all other villagers, Mak Ijah is staying put in her flooded house, expressing a sense of attachment to her homeland and the language of fear for the uncertain future (ex.2). The narratives of victims of the sea level rising initially believe that the flood is temporary and that they might be able to fix it, but they were surprised that even after a few times raising the levels of their house floors, the water keeps rising up until they finally realize they could not stay.

They must focus on their local daily survival facing the unstoppable calamity, because they do not see any impact of government efforts or international cooperation on their lives. It is easier for the experts and government officials to continue encouraging them to move out the flooded village without sufficient supports. The inundated houses, infrastructure, public faculties, including places of worship and cemeteries constitute a memory of cultural 
and social landscape that have been parts of their live of generations. The narratives of the displaced must involves telling stories of these memories as part of rituals of grieving, before finally deciding to abandon them for good. These stories maybe expressed in the use of the term bertahan (staying put) (ex $2 \& 3)$.

1. "kulo maune, kerja tandur terus.... tandur pari.. nandur jagung.. Lah kok soyo suwi rob terus soyo maju...." "akhire do nggo tambak. ..kok terus nemen...kok malah dadi laut".

"initially, I farmed rice, planting rice and corn.. Surprisingly, the tidal flood got expansively worse and worse; then we made it into a fish farm,.. but the tidal flood got worse and the area became sea."

2 "Saya bertahan di sini, meski tidak punya uang, tidak bisa makan, ya seadanya. Nyatanya sudah tidak bisa minta bantuan ke teman atau tetangga,"

"I keep staying here, even though I don't have money to buy food. So I eat minimally. In fact, I can't ask help from other people or neighbors'

3 "Saya tidak ingin pindah. Sudah diniati di sini, kami tinggal di sini,"

"I do not want to move. I Already intended to live here. We have lived here"

Once they decided to leave, they go through the ritual of pamit (farewell) due to close relationship among the village dwellers, in 2015 the rate of departure was $10 \%$ a year. This is not just a narrative of climate change, but a cultural and social narrative of human relationship with the changing nature.

\section{The Narrative of Tidal Flood}

Another selected narrative is part of a report series about the Indonesian coastline threatened to sink on the BBC News Indonesia website. The narrative is about the story of one family in Demak surviving in the drowning district. However, instead of reporting the main story, the report comprises an evaluation of tidal sea water as a natural phenomenon.

The loss of a district is not only seen as a natural phenomenon, but also as a social phenomenon because it deals with the people's lives and survival [8]. The narrative discourse that was built to construct social events of the disappearance of Bedono villages shows how the author constructs human relations with nature by appreciating their efforts to protect invaluable humanity as part of nature $[5,7]$. In addition, the way the author chose lexicogrammar to represent sea level rising constitutes her regards for the natural phenomenon. The following data are examples of her appreciation constructed to respect the tidal flood as a natural phenomenon.

4. Banjir rob yang terjadi selama 20 tahun terakhir telah menenggelamkan dua dusun di Demak,

'The tidal flood that has happened over the past 20 years has sunk two districts in Demak'

5. ...banjir yang biasanya menerjang setahun sekali, lambat laun menjadi banjir permanen.

'Floods that usually hits once a year, has gradually become permanent flood'

6. Kalau rob masuk rumah, air bisa menggenangi rumah.

'If tidal flood reached houses, water can flood the them'

7. Dengan kondisi rumah yang dikepung air laut, setiap hari Mak Jah harus berjibaku dengan air pasang yang selalu menerjang sejak petang hingga tengah malam.

'In the condition that the house is besieged by sea water, every day Mak Jah must struggle with the tide that always crashes from dusk to midnight' 


\section{8. ... genangan air laut telah membuat lapuk dinding rumahnya yang terbuat dari papan .... \\ ... puddle of sea water has weathered the walls of his wooden house ....}

The five data are the excerpts of the narrative text that represents the relation between the natural phenomenon and local inhabitants. High tide that is realized using noun group banjir rob, banjir, rob (tidal flood), air laut (sea water), air pasang (high tide), exemplify a natural phenomenon. In Indonesian, the neutral term referring to this phenomenon is air pasang 'high tide'. However, the choice of the word rob was aimed at focusing on the intrusion of the sea water into the land as a result of sea level rising. For the local community, this phenomenon is a normal natural phenomenon happening each year. However, just as other natural phenomena such as flood, abrasion, and land subsidence, rob has a negative significance. That is why the author also use a noun group banjir rob (tidal flood) to imply that the flood, commonly due to conspicuous heavy rainfall in other areas, happens in these villages due to surreptitious nature of $r o b$. The author's choice and portrayal of such lexical item emphasize the evil and negative image of high tide phenomenon [5].

Placing the tidal flood as a participant, the author describes the flood as an entity doing physical processes of drowning two villages (ex. 4), of crashing down the villages (ex. $5 \&$ 7), of inundating houses (ex.6), of besieging (ex.7), and of causing hardships (ex. 8). All the physical progressions are realized through verbs that have negative connotation. The verb "menenggelamkan" (to sink) is normally juxtaposed with undesirable consequences, or it is used to depict the articulating power of participant. In example 4, the verb is used to represent the tidal flood as an active participant exerting its power to sink two villages in Demak. The verb "menerjang" (to crash down) in example 5 represents the event of intruding sea water into land area as a symbolic battle with the two villages as the patient or target. Using the verb "menggenangi" (to inundate) in examples 6 and 8, the author depicted the tidal water as an active agent which treated the occupied houses of the villages as the target of the attack of inundation. Example 7 also represents the power of sea water to besiege houses, creating the images of the sea water as a troop and the houses of the villages as the enemies.

Other linguistic expressions that represent the impact of high tide is the use of adjuncts. Temporal adjunct telah (already) (ex.4 and 8), biasanya (usually) (ex.5), setiap hari (every day) and selalu (always) (ex.7) emphasize the completeness and repetition of the events. Using such adjuncts, the author signifies that the negative effects of tidal flood in the villages have happened regularly for a long time. Another adjunct used to describe the condition is a modal adjunct harus 'must' (ex.7), where the author depicted the powerful relation between sea water and Mak Ijah, a member of the only family that has no choice but continue living in the inundated village.

The descriptive analysis of lexicogrammar depicting the high tide and its consequences leads to altered images of natural phenomenon created by the author. That is, positioning natural event as an authoritative agent that exerts its power against humanity, devastating or wiping out not only their livelihood and community, but also their social network, tradition, and culture. This is a clear expression of adverse attitude against nature as the human enemy.

The author created this narrative as a part of a larger discourse of a report about Indonesian coastline under the threat of inundation by BBC News. The media produced a discourse as a warning to human beings, but instead of using formal scientific genre, it employs touching personal narratives [9] to varieties of audiences. Positioning nature as an active entity exercising its power against human beings may also help create an awareness of the importance of environmental protection. However, the discourses that emphasized the damages that nature has cost and lack of discourses on human's responsibilities in maintaining the environment shaped the views of the relationship between nature and human beings [3]. The discourse helps form human views of nature as enemy instead of inseparable 
part of human life that has to be taken care of. Producing discourses that position nature side by side with human being and narrate complementary relationship between the two may help generate a balancing alternative discourses.

\section{The Narrative of the Sinking District as Tourist Destination}

The third discourse related to the inundated district phenomenon concerns the district as a tourist destination. The discourse of tourism depicts some destinations that have been flooded as interesting and worth appreciation. The tourism advertorial texts produced discourses that exploit lexicogrammars expressing positive values of the inundated destination as being marketable. The former inhabitants with the devastating memories of the vanishing villages are exposed and aware of the discourse of tourism. Analyzing this type of discourse is intriguing, because discourses can have the power to change the perspective of a social phenomenon from tragedy to entertainment.

Using an appreciation system, we found that the text consists of positive appreciation more than that of negative attitudes. Describing the Morosari beach, the only beach in Bedono district, the producer used positive adjective "unik" (unique) and predicator "memiliki daya tarik" (attractive). The word unik is used to substitute the word "indah" (beautiful) that has strong collocation with the word pantai 'beach'. This is the discourse strategy made by the author to construct the object, expressing the positive evaluation or appreciation to present various activities that can be enjoyed by tourists visiting the site. Examples of these activities are shown in the following data:

9. Kamu masih bisa menikmati laut dengan bersantai di saung-saung yang tersedia.

'You can still enjoy the sea by sitting relax in the available gazebos'

10. Kamu juga bisa menyewa kapal untuk berkeliling kawasan ini.

'You can also rent a boat to go around this area.'

11. Nggak jauh dari pantai, kamu bisa berkunjung ke sebuah "kampung tenggelam".

'Not far from the beach, you can visit a "sinking village".'

12. Kamu bisa melihat deretan pemancing berjejer di batu-batu pemecah ombak itu.

'You can see a row of fishermen lined up on the breakwater rocks.'

13. Saat panen, kamu bisa melihat kerang-kerang hijau yang sedang berkembang di keramba tersebut.

'In harvest time, you can see green shells in the cage.'

14. Kalau belum puas mencicipi keripik brayo, kamu juga bisa berkunjung sekaligus membeli oleh-oleh keripik kulit ikan. Di jalan menuju Desa Bedono, kamu bisa menemukan satu sentra produksi keripik kulit ikan. Di sentra produksi itu, kamu bisa melihat proses pembuatan keripik gurih itu secara langsung.

'If you have not been satisfied tasting brayo chips, you can also visit the producers and buy souvenirs of fish skin chips. On the way to Bedono district, you can find a production center of fish skin chips. At the production center, you can directly watch the process of making these savory chips.'

The data shows how the author constructed the sinking district as the tourist destination that provide the visitors with venues for entertaining activities such as shown in example 9 to 14. Instead of describing the noun laut (sea), using epithet such as jernih (clean), and indah (beautiful), the author focused on the way the visitors can enjoy the sea, such as sitting in the gazebos (ex. 9) and sight-seeing using boats (ex. 10). This discourse attempts to depict the Morosari beach in a positive term. The daily activities such as fishing, harvesting green clams, and making fish skin chips are constructed to create positive images of the inundated district. The verb berjejer (lined up) is used construct beautiful images of the setting of the 
site, instead of merely stating that fishermen are working in the sand-less beach. In addition using adjective gurih 'tasteful' as a qualifier, the producer created a favorable image of the food.

As a sinking district, Bedono has a reputation of having negative images among the local and regional communities, because the local and national newspaper inclines to report the sites as the center of as natural disasters, such as the negative impacts experienced by Mak Ijah's family. Through this tourism advertising genre, the author represented relics of the natural disaster from the distinctive point of view as seen in the following examples

15. Di tempat itu, kamu masih bisa menjumpai puing-puing rumah yang ditinggalkan, yang tentu saja telah digenangi air.

'In that place, you can still find the ruins of houses left because of the tidal flood'

16. Kalau cermat mengamati, beberapa bangunan masih terlihat kokoh, salah satunya sebuah musala yang berada tepat di pinggir trek perahu.

'If you carefully observe, some buildings still look sturdy, one of them is a musala located right on the edge of the boat track.'

17. Kamu juga bakal bertemu dengan makam Syekh Abdullah Mudzakkir yang nggak tenggelam meski diterjang rob. Syekh Mudzakkir adalah tokoh agama Desa Bedono. Tiap hari, terlebih pada akhir pekan, makam tersebut selalu dipadati peziarah.

'You will also meet the tomb of Sheikh Abdullah Mudzakkir that did not sink even though he was hit by a rob. Syekh Mudzakkir is a religious figure in Bedono Village. Every day, especially on weekends, the tomb is always full of pilgrims.'

18. Laiknya Pantai Marina di Semarang, Pantai Morosari hampir nggak memiliki pasir. Pantai utara itu lebih menyerupai dermaga karena air yang ada di pantai sudah cukup tinggi. Kalau kamu berharap bisa bermain air dengan pasir putih, singkirkan pikiran itu dulu. Kendati demikian, kamu masih bisa menikmati laut dengan bersantai di saung-saung yang tersedia.

'Like the Marina Beach in Semarang, Morosari Beach has almost no sand. The North Coast is more like a doc because the level of the sea water is quite high. If you wish to do marine activities and to enjoy white sand, forget them. Nevertheless, you can still enjoy the sea by relaxing in the available gazebos'

19. Dulu di Desa Bedono ada dua dukuh atau kampung pesisir, yakni dusun Tambaksari dan Rejosari. Nahas, rob melahap dua dusun tersebut sekitar 1990an. Para penduduk pun terpaksa bedol desa. Mereka dipindahkan di Desa Sidogemah, Kecamatan Sayung, nggak jauh dari Bedono.

'There were two coastal districts in Bedono village, namely Tambaksari and Rejosari. Unfortunately, tidal flood devoured the two districts around the 1990s. The residents were forced to leave the village. They were moved in Sidogemah Village, Sayung District, not far from Bedono.'

The data show that the author strategically employed certain linguistic expressions to represent the social circumstances using positive valuation. Examples 15 and 19 represent the relic of the disaster as valuable items to see and appreciate. The discourses change the perspective of viewing the impact of the disaster from ruins due to inundation into valuable objects of appreciation. By de-emphasizing the tragedy of natural disaster, the author epitomized the condition of the beach of the sinking district that does not have any visible sand to enjoy (ex. 18) as sources of beauty and pleasure. This discourse influences the way human beings should view and treat nature and natural phenomena. 


\section{Conclusion}

The analysis of the three different texts shows that, through discourse, authors can construct natural phenomenon as a social phenomenon from various viewpoints. Tidal flood and sea level rising are natural phenomena that can happen anywhere. However, whenever the natural phenomenon interferes with human life, people can treat nature as a challenge, an enemy, and even a threat to humanity. The human attitude toward nature can be seen through the news media's choice of lexicogrammar in producing these discourses. Choosing particular words or phrases rather than the others reflects the way of selecting which parts natural phenomenon they want to portray as reality.

Based on the viewpoint that discourse is a means of representing the world, expressing social relations, and constructing reality, this research shows that producing different discourses of the sinking districts in Demak reveals the way the text producers position nature in a social relation. The Pasijah's life is manipulated in narrative discourse by positioning her as the victim of the natural disaster with the motive of attracting the sympathy of the readers. In addition, the narrative of tidal flood accompanying the story of Pasijah's life is constructed to position high tide as an enemy of the inhabitants, amplifying the main narrative with Pasijah as the victim. However, such narrative produces another meaning in terms of social relation; that is, nature has more power to destroy human habitation. Such discourse strategy may impact reinforcing member resource of readers and inhabitants' awareness that there is differing relation between humans and nature. Constructing discourses of disaster phenomenon can use positive appreciation for advertising purposes that may shape positive attitude among humans in viewing nature.

\section{References}

1. J. Stephenson, B. Barton, G. Carrington, D. Gnoth, R. Lawson, \& P. Thorsnes, . E.P 38(10), 6120-6129 (2010).

2. S. Bushell, T. Colley, M. Workman. Nat. Clim. Change, 5, 971-973. (2015).

3. N. Fairclough, Critical discourse analysis. (1995).

4. T. A. van. Dijk, Principles of critical discourse analysis. (1993)

5. J.R. Martin, and D. Rose. Working with discourse: Meaning beyond the clause (2007)

6. R. Wodak, and M. Meyer. Methods for Critical Discourse Analysis. (2009).

7. M. A. K. Halliday., C. M. I. Matthiessen. An Introduction to Functional Grammar. (2004).

8. N. Fairclough. Analysing Discourse : Textual Analysis for Social Research. (2003)

9. M. Bednarek. Evaluation in Media Discourse: Analysis of a Newspaper Corpus. (2006) 